\title{
PERANCANGAN ALAT PENGOLAHAN AIR GAMBUT SEDERHANA MENJADI AIR MINUM SKALA RUMAH TANGGA
}

\author{
Ardy Rubinatta ${ }^{1}$, Rizki Purnaini ${ }^{1}$, Kiki Prio Utomo ${ }^{1}$ \\ ${ }^{1}$ Program Teknik Lingkungan, Fakultas Teknik, Universitas Tanjungpura Pontianak, \\ email : ardyrubinatta7@gmail.com
}

\begin{abstract}
ABSTRAK
Air gambut merupakan salah satu sumber daya air yang masih melimpah untuk itu perlu di rancang alat pengolahan dengan sumber air baku air gambut untuk menjadi air minum skala rumah tangga. Perancangan alat pengolahan air gambut menjadi air minum dengan proses netralisasi, koagulasi, sedimentasi, filtrasi dan disinfeksi. Proses netralisasi dan koagulasi menggunakan kapur tohor juga tawas. Proses sedimentasi menggunakan tangki sedimentasi. Proses filtrasi menggunakan tabung filtrasi dengan media filter kerikil, pasir, zeolit dan karbon aktif. Proses desinfeksi dengan menggunakan tabung ultraviolet. Perancangan alat dibangun di daerah Sungai Raya Kabupaten Kubu Raya. Penentuan dosis dengan metode jar test dilakukan dengan penentuan dosis koagulan tawas dan netralisasi kapur tohor yakni 350 $\mathrm{mg} / \mathrm{l}$ dan $150 \mathrm{mg} / \mathrm{l}$. Kualitas air baku belum memenuhi standar persyaratan kualitas air baku PERMENKES RI NO.416/Menkes/ Per/ IX/ 1990 , yaitu pH 5,5 kekeruhan 28 NTU, tingkat intensitas warna yang sangat tinggi 347 PtCo, besi $0,62 \mathrm{mg} / \mathrm{l}$, zat organik $18,4 \mathrm{mg} / \mathrm{I}$ dan total coliform $17 \times 10^{2}$ MPN. Sedangkan parameter lain, yaitu TDS 403 $\mathrm{mg} / \mathrm{l}$, kimia logam, kimia non logam, E. coli suhu, bau dan rasa sudah memenuhi baku mutu yang diperbolehkan. Kualitas air hasil pengolahan rata-rata parameter fisik dan kimia air gambut mengalami perbaikan, pH naik menjadi netral (pH 6,8), parameter warna turun 97,12\% (10 Pt-Co ), parameter kekeruhan turun 76,21\% (6,7), parameter TDS turun sebesar $96,34 \%(14,8 \mathrm{mg} / \mathrm{l})$, zat organik turun sebesar $85,39 \%(12 \mathrm{mg} / \mathrm{l})$, parameter besi turun menjadi $62,09 \%$ (0,23 mg/l). Kapasitas pengolahan 3,5 liter/menit atau 210 liter/jam dan kebutuhan biaya produksi untuk 1000 liter yakni Rp. 2.550,-. Biaya yang di perlukan untuk membuat alat pengolahan Rp. 5.120.500,--
\end{abstract}

Kata Kunci : Air Gambut, Alat Pengolahan, Rumah Tangga

\begin{abstract}
Peat water is one of water resources are still abundant for the necessary processing tool designed with raw water sources peat water into drinking water for household scale. Design of water treatment equipment for drinking water with peat neutralization, coagulation, sedimentation, filtration and disinfection. Neutralization and coagulation using alum as well quicklime. Sedimentation process using a sedimentation tank. Filtration process using a tube with a filter media filtration gravel, sand, zeolite and activated carbon. Disinfection using ultraviolet tube. Design tool built in Sungai Raya area Kubu Raya district. Dose determination with jar test method is done by determining the dose of coagulant alum and lime neutralization ie $350 \mathrm{mg} / \mathrm{l}$ and $150 \mathrm{mg} / \mathrm{I}$. Water quality standards do not meet water quality requirements PERMENKES RI NO.416/Menkes / Per / IX / 1990, the turbidity of 28 NTU pH 5,5, the intensity level is very high color $347 \mathrm{Pt}$ - Co , 0,62 mg iron / I, organic matter $18,4 \mathrm{mg} / \mathrm{I}$ and total coliform $17 \times 10^{2} \mathrm{MPN}$. While the other parameters, namely TDS $403 \mathrm{mg} / \mathrm{I}$, chemical metal, non-metal chemistry, E. coli temperature, smell and taste it meets quality standards are allowed. Water quality treatment average physical and chemical parameters improved

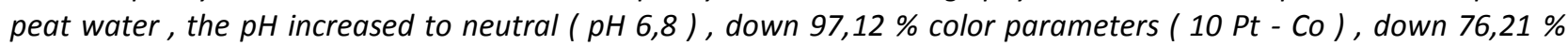
turbidity parameters $(6,7)$, the parameter TDS decreased by 96,34 \% (14,8 $\mathrm{mg} / \mathrm{I})$, organic matter decreased by 85,39\% ( $12 \mathrm{mg} / \mathrm{l}$ ), iron parameters decreased to $62.09 \%(0,23 \mathrm{mg} / \mathrm{I})$. Processing capacity of 3,5 liters / minute or 210 liters / hour and cost requirements for the production of 1000 liters at Rp 2.550, - . Costs that need to make processing tools Rp. $5.120 .500,-$.
\end{abstract}

Keywords: Peat Water, Processing Equipment, Household 


\section{Pendahuluan}

Sebagian besar lahan di Kalimantan Barat merupakan lahan gambut dengan luas mencapai 4,6 juta hektar atau sekitar 24,9\% dari luas lahan gambut di Indonesia. Sumur di daerah bergambut umumnya airnya bewarna coklat, berkadar asam humus, zat organik dan besi yang tinggi. Karena air gambut memiliki tingkat kekeruhan dan warna yang tinggi menyebabkan secara fisik air gambut tidak layak sebagai sumber air minum sehingga masyarakat di Kalimantan Barat lebih memilih menggunakan air hujan sebagai sumber air minum.

Kondisi ini mendorong timbulnya rancangan-rancangan baru dalam pengolahan air gambut sehingga dapat dimanfaatkan untuk air minum karena air gambut merupakan salah satu sumber air permukaan yang dapat digunakan sebagai air minum bagi masyarakat yang tinggal di lahan gambut khususnya masyarakat Kota Pontianak dan Kabupaten Kubu Raya yang memiliki lahan gambut terbesar di Kalimantan Barat.

\section{Tinjauan Pustaka}

\section{A. Air Gambut}

Air gambut adalah air permukaan yang banyak terdapat di daerah berawa atau dataran rendah terutama di Sumatera dan Kalimantan, yang mempunyai ciri-ciri sebagai berikut (Kusnaedi, 2006):

(1). Intensitas warna yang tinggi (berwarna coklat kemerahan).

(2). Keasamannya tinggi ( $\mathrm{pH}$ yang rendah).

(3). Kandungan zat organik yang tinggi.

(4). Kekeruhan dan kandungan partikel tersuspensi yang rendah.

(5). Kandungan kation yang rendah.

Warna coklat kemerahan pada air gambut merupakan akibat dari tingginya kandungan zat-zat organik dalam air gambut tersebut berasal dari dekomposisi bahan organik seperti daun, pohon, dan kayu. Zat-zat organik ini dalam keadaan terlarut serta memiliki sifat sangat tahan terhadap mikroorganisme dalam waktu yang cukup lama (Syarfi, 2007).

\section{B. Permasalahan Air Gambut Terhadap Penyedian Air Bersih}

Air gambut tergolong air yang tidak memenuhi persyaratan air bersih yang telah ditetapkan oleh Peraturan Menteri Kesehatan RI No. 492/MENKES/PER/IV/2010 tanggal 19 April 2010, beberapa unsur yang tidak memenuhi persyaratan adalah sebagai berikut :

1. Segi estetika yaitu dengan adanya warna, kekeruhan dan bau pada air gambut akan mengurangi efektifitas usaha desinfeksi, karena mikroba terlindung oleh zat padat tersuspensi, baik yang bersifat anorganik maupun yang organik. Hal ini tentu berbahaya bagi kesehatan bila terdapat mikroba yang pathogen. Disamping itu penyimpanan terhadap standar yang diterapkan akan mengurangi penerimaan masyarakat terhadap air tersebut yang selanjutnya dapat mendorong masyarakat untuk mencari sumber air lain yang kemungkinan tidak aman. (Sutrisno, 1991).

2. $\mathrm{pH}$ rendah pada air gambut menyebabkan air terasa asam yang dapat menimbulkan kerusakan gigi dan sakit perut (Notodarmojo, 1994).

3. Kandungan zat organik yang tinggi dapat menjadi sumber makanan bagi mikroorganisme dalam air yang dapat menimbulkan bau apabila zat organik tersebut terurai secara biologis dan jika dilakukan desinfeksi dengan larutan khlor akan membentuk senyawa organokhlorine yang bersifat karsinogenik (Notodarmojo, 1994).

4. Tingginya kadar besi ( $\mathrm{Fe}$ ) pada air merupakan suatu hal yang harus diperhatikan dalam penyediaan air bersih bagi masyarakat. Mengingat bahwa tingginya kadar Fe akan mengurangi segi estetika dan akan mengurangi efektifitas usaha desinfeksi karena mikroba terlindung oleh zat tersuspensi tersebut. Tingginya kadar besi pada air menyebabkan air berwarna merah kecoklatan dan berbau logam sehingga menimbulkan keengganan untuk mengkonsumsinya . (Sutrisno, 2006). 
5. Endapan mangan $(\mathrm{Mn})$ akan memberikan noda-noda pada bahan/benda-benda yang berwarna putih. Adanya unsur ini dapat menimbulkan bau dan rasa pada minuman. (Sutrisno, 2006).

\section{Proses Pengolahan Air Gambut}

Menurut Kusnaedi (2006), ada 2 tahap proses pengolahan air gambut yaitu terdiri dari :

1. Tahap Koagulasi, Flokulasi,absorbsi, dan sedimentasi. Menurut kusnaedi (2006), koagulasi adalah proses pembubuhan bahan kimia ke dalam air agar kotoran dalam air yang berupa padatan tersuspensi misalnya zat warna organik, lumpur halus, bakteri dan lain-lain dapat menggumpal dan cepat mengendap. Tahap ini berlangsung pada ember pertama dengan cara mencampurkan zat koagulasi yang dilengkapi dengan pengaduk. Bahan koagulan yang dapat digunakan antara lain : kapur, tawas, tanah liat (lempung) setempat, dan tepung biji kelor.

2. Tahap Penyaringan (Filtrasi) Filtrasi adalah proses penyaringan untuk menghilangkan zat padat tersuspensi (yang diukur dengan kekeruhan) dari air melalui media berpori-pori. Pada proses penyaringan ini zat padat tersuspensi dihilangkan pada waktu air melalui lapisan materi berbentuk butiran yang disebut media filter.

\section{Metode Perancangan}

\section{A. Lokasi Perancangan}

lokasi perancangan alat pengolahan di perumahan kosgoro Kecamatan Sungai Raya Dalam Kabupaten Kubu Raya.Pengujian parameter dilakukan di Laboratorium Teknik Lingkungan Fakultas Teknik Untan, Laboratorium Kesehatan dan Laboratorium Teknologi Hasil Pertanian Fakultas Pertanian Untan

\section{B. Tahap Perancangan}

Adapun tahap perancangan sebagai berikut:

a. Tahap Persiapan

Menyiapkan segala kebutuhan alat dan bahan.

b. Tahap pembuatan alat adapun langkah-langkah dalam pembuatan alat yakni sebagai berikut :

1. Tabung Pengaduk

- Menyiapkan pipa PVC 5" dan 8"

- Menyiapkan botol dosis, selang, connector selang, socket drat dalam

- Memotong pipa PVC 8" sepanjang $80 \mathrm{~cm}$ dan pipa PVC 5" sepanjang $70 \mathrm{~cm}$.

- Menyambungkan botol dosis dengan selang infus dengan ujungnya yang dilekatkan pada socket drat dalam $3 / 4^{\prime \prime}$.

- Melubangi PVC 5 " bagian atas dan bawas sebesar 1 " melilitkan selang pada pipa PVC 5" sepanjang $70^{\prime \prime}$.

- Melekatkan selang dengan connector pipa pada socket drat dalam 3/4".

- Menyatukan semua bagian botol dosis dengan pipa PVC 5“ yang dililitkan secara spiral dan Menutup semua bagian dengan pipa PVC 8" dengan bagian bawah dan atas dilubangi sebesar 3/4".

2. Tangki sedimentasi dan pondasi

- Memesan tangki sedimentasi dengan bahan fiber berkapasitas 1000 liter dengan bagian bawah berbentuk kerucut untuk membuat kotoran atau endapan dan memasang katup berukuran 1" di bagian bawah tangki untuk saluran pembuangan.

- Membuat pondasi besi dengan tinggi 2 meter.

3. Alat filter

- Memotong pipa PVC 8" sepanjang $130 \mathrm{~cm}$ dan membuat 3 buah lubang pada tutup bagian atas, 1 lubang dengan ukuran 3 " dan 2 buah lubang dengan ukuran 3/4". Memasukkan dan merekatkan CO dengan lem pada lubang 3 inci dan pada lubang $3 / 4 "$ connector pipa. 
- Menyambung tiap bagian tee, tee socket drat, elbow, elbow socket drat , katup, pipa PVC 3/4"dan nozzle

- Melubagi bagian samping bawah pipa PVC 8" berukuran 3/4" dan dimasukkan connector pipa 3/4".

- Dihubungkan antara bagian tutup atas dengan dengan bagian bawah

4. Tabung ultraviolet

- Menyiapkan lampu ultraviolet 20 watt dan membungkus dengan bagian plastik anti air. Membuat pelindung dengan pipa PVC 5" sepanjang $60 \mathrm{~cm}$ dan direkatkan dengan penjepit dan dipasang horizontal lalu bagian depan dipasang CO berukuran $5^{\prime \prime}$.

Perancangan yang dilakukan adalah perancangan alat pengolahan air gambut skala lapangan dengan mengetahui efektifitas alat pengolahan dalam mengolah air gambut menjadi air minum yang dilakukan tiga kali pengulangan untuk mendapatkan data yang akurat. Rancangan yang dilakukan dengan Pre and Post Test Design yaitu pengujian dilakukan sebelum dan sesudah penggunaan alat pengolahan.

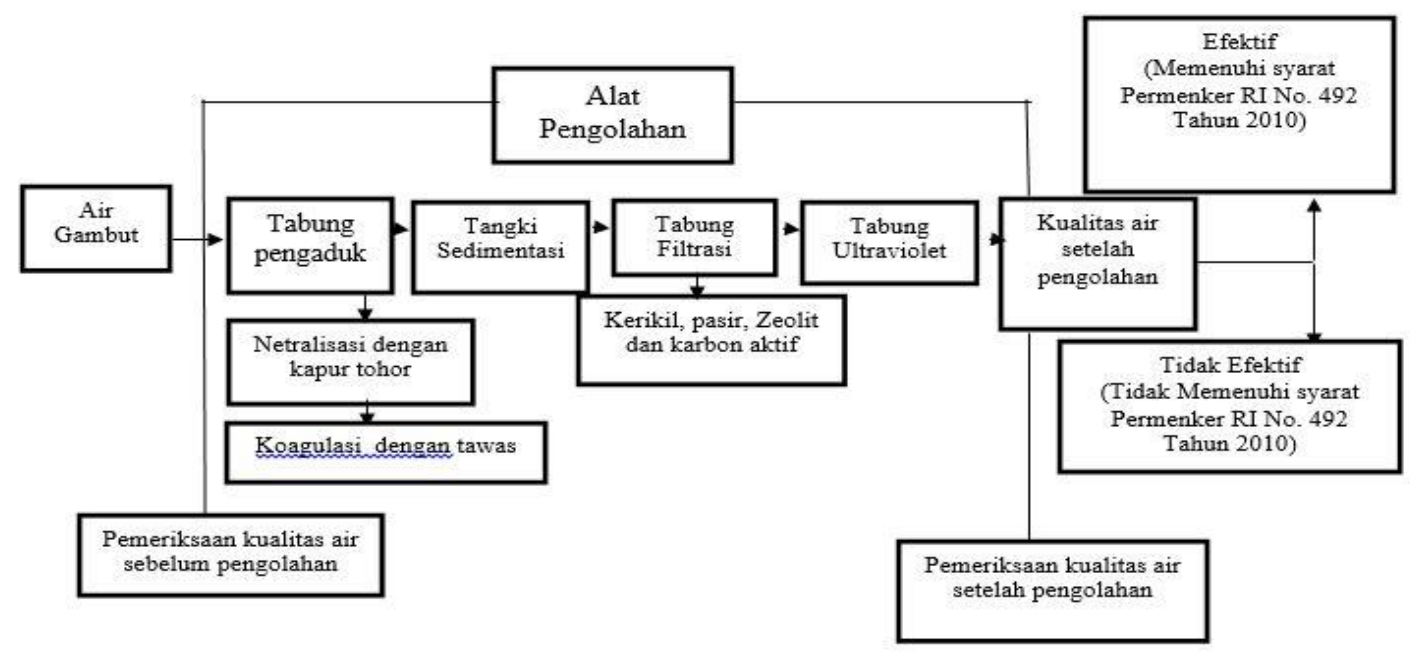

Gambar 1. Diagram Alir Perancangan

\section{Analisis Perancangan}

\section{A. Perhitungan Bak Koagulan}

Tujuan pengadukan cepat dalam pengolahan air adalah untuk menghasilkan turbulensi air sehingga dapat mendispersikan bahan kimia yang akan dilarutkan dalam air.

Untuk pelarutan tawas dan kapur tohor

- $T d$ (waktu tinggal hidrolik): 20 detik

- $\mathrm{G}$ (Gradien kecepatan) $: 10$ detik $^{-1}$

Head loss :

$h=\frac{\mu \cdot t}{\rho \cdot g} G^{2}$

$\mu$ : viskositas dinamik air, temperatur $25^{\circ} \mathrm{C}=0,9 \times 10^{-6} \mathrm{~m}^{2} /$ detik

$p: 1000 \mathrm{~kg} / \mathrm{m}^{3}$

$\mathrm{t}$ : waktu tinggal hidrolik

$\mathrm{G}$ : gradien kecepatan

$$
\begin{aligned}
h & =\frac{\left(0,9 \times 10^{-6}\right) \times(20) \times 3600}{1000 \times 9,81} 10^{2} \\
& =\frac{6,48}{9810}
\end{aligned}
$$


$=6,6 \times 10^{-4} \mathrm{~m}$

\section{B. Perhitungan Tangki Sedimentasi}

Luas permukaan tangki sedimentasi dapat dihitung dengan rumus :

$$
\mathrm{A}=\frac{Q}{V}
$$

$\mathrm{Q}=15,6$ liter $/$ menit $=2,6 \times 10^{-4} \mathrm{~m}^{3} /$ detik

$\mathrm{V}=0,81 \mathrm{~m} / \mathrm{jam}=0,81 / 3.600=2,26 \times 10^{-4} \mathrm{~m} /$ detik

Maka, $\mathrm{A}=\frac{Q}{V}=\frac{2,6 \times 10^{-4}}{2.26 \times 10^{-4}}=1,15 \mathrm{~m}^{2}$

Dimensi tangki sedimentasi dapat dilihat pada gambar 2 .

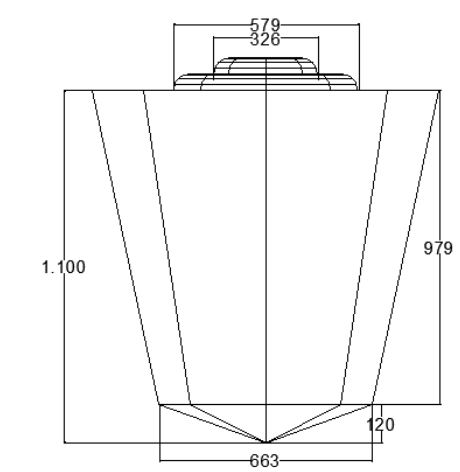

Gambar 2. Dimensi Tangki Sedimentasi

\section{Perhitungan Tabung Filtrasi}

Untuk hasil yang efektif, aliran pada saat filtrasi harus dijaga agar laminar dengan bilangan Reynolds, $\operatorname{Re}<1000$.

Bilangan Reynold dihitung dengan menggunakan persamaan berikut :

$$
R e=\frac{d \cdot v}{\mu} .
$$

Dimana :

Re : bilangan Reynolds

$\mu$ : viskositas dinamik air, temperatur $25^{\circ} \mathrm{C}=0,9 \times 10^{-6} \mathrm{~m}^{2} /$ detik

$v$ : kecepatan air melalui media filter ( $\mathrm{m} /$ detik)

$d \quad$ : diameter kerikil/pasir $(\mathrm{m})$

- Bilangan Reynold media kerikil:

Diameter kerikil $=32 \mathrm{~mm}=3,2 \times 10^{-2} \mathrm{~m}$

$A=\frac{1}{4} \times 3,14 \times 0,2032 \times 0,2032=0,0324 \mathrm{~m}^{2}$

$Q=9,2$ liter $/$ menit $=\frac{9,2}{1 \times 60}=1,53 \times 10^{-4} \mathrm{~m}^{3} /$ detik

$\mathrm{V}=\frac{Q}{A}=\frac{1,53 \times 10^{-4}}{3.24 \times 10^{-2}}=4,73 \times 10^{-3} \mathrm{~m}^{2}$

$R e=\frac{d . v}{\mu}$

$\operatorname{Re}=\frac{3,2 \times 10^{-2} .4,73 \times 10^{-3}}{0,9 \times 10^{-6}}=168$

- Diameter pasir $=1 \mathrm{~mm}=1 \times 10^{-3} \mathrm{~m}$

$A=\frac{1}{4} \times 3,14 \times 0,2032 \times 0,2032=0,0324 \mathrm{~m}^{2}$

$Q=9,2$ liter $/$ menit $=\frac{9,2}{1 \times 60}=1,53 \times 10^{-4} \mathrm{~m}^{3} /$ detik

$\mathrm{V}=\frac{Q}{A}=\frac{1,53 \times 10^{-4}}{3.24 \times 10^{-2}}=4,73 \times 10^{-3} \mathrm{~m}^{2}$

$R e=\frac{d . v}{\mu}$ 
$\operatorname{Re}=\frac{1 \times 10^{-3} .4,73 \times 10^{-3}}{0.9 \times 6}=5$

- Bilangan Reynold media karbon aktif:

Diameter karbon aktif $=8 \mathrm{~mm}=8 \times 10^{-3} \mathrm{~m}$

$\mathrm{A}=\frac{1}{4} \times 3,14 \times 0,2032 \times 0,2032=0,0324 \mathrm{~m}^{2}$

$Q=9,2$ liter $/$ menit $=\frac{9,2}{1 \times 60}=1,53 \times 10^{-4} \mathrm{~m}^{3} /$ detik

$\mathrm{V}=\frac{Q}{A}=\frac{1,53 \times 10^{-4}}{3.24 \times 10^{-2}}=4,73 \times 10^{-3} \mathrm{~m}^{2}$

$\operatorname{Re}=\frac{d . v}{\mu}$

$\operatorname{Re}=\frac{8 \times 10^{-3} \times 4,73 \times 10^{-3}}{0,9 \times 10^{-6}}=42$

- Bilangan Reynold media zeolit:

Diameter zeolit $=8 \mathrm{~mm}=8 \times 10^{-3} \mathrm{~m}$

$A=\frac{1}{4} \times 3,14 \times 0,2032 \times 0,2032=0,0324 \mathrm{~m}^{2}$

$Q=9,2$ liter $/$ menit $=\frac{9,2}{1 \times 60}=1,53 \times 10^{-4} \mathrm{~m}^{3} /$ detik

$\mathrm{V}=\frac{Q}{A}=\frac{1,53 \times 10^{-4}}{3.24 \times 10^{-2}}=4,73 \times 10^{-3} \mathrm{~m}^{2}$

$\operatorname{Re}=\frac{d . v}{\mu}$

$R e=\frac{5 \times 10^{-3} \times 4,73 \times 10^{-3}}{0,9 \times 10^{-6}}=42$

Maka bilangan reynolds tiap media filter dapat dilihat pada tabel 1.

Tabel 1. Bilangan reynold media filter

\begin{tabular}{|c|l|c|c|}
\hline No & \multicolumn{1}{|c|}{ Media } & Bilangan Reynold & Aliran \\
\hline 1. & Kerikil & 168 & Laminar \\
\hline 2. & Pasir & 5 & Laminar \\
\hline 3. & Karbon aktif & 42 & Laminar \\
\hline 4. & Zeolit & 42 & Laminar \\
\hline
\end{tabular}

Untuk menghitung Headloss pada saat proses penyaringan digunakan persamaan KozenyCarman, persamaan ini hanya berlaku untuk aliran laminar dimana bilangan Reynolds $(\operatorname{Re}<1000)$.

Untuk menghitung Headloss pada saat proses penyaringan digunakan persamaan KozenyCarman. Adapun persamaannya adalah:

$$
\frac{\Delta P}{L}=\frac{150 \cdot v \cdot \mu\left(1-P o^{2}\right)}{g \cdot \varphi \cdot d^{2} \cdot P o^{2}}
$$

Dimana :

$\Delta P:$ Head loss $(\mathrm{m})$

$\mu$ : viskositas dinamik air, temperatur $25^{\circ} \mathrm{C}=0,9 \times 10^{-6} \mathrm{~m}^{2} /$ detik

$v$ : kecepatan air melalui media filter ( $\mathrm{m} /$ detik)

Po : porositas

$d$ : diameter $(\mathrm{m})$

g : percepatan gravitasi, $9,81 \mathrm{~m} / \mathrm{d}^{2}$

$\varphi$ : koefisien bentuk, berkisar antara 0,6-0,95

$L$ : tinggi media (m) 
viskositas dinamik air, temperatur $25^{\circ} \mathrm{C}=0,9 \times 10^{-6} \mathrm{~m}^{2} /$ detik

- Headloss media kerikil :

Porositas $=0,4$

koefisien bentuk $\varphi=0,65$

percepatan gravitasi $(\mathrm{g})=9,81 \mathrm{~m} / \mathrm{d}^{2}$

$\mathrm{L}=0,25 \mathrm{~m}$

$\mathrm{d}=32 \mathrm{~mm}=3,2 \times 10^{-2} \mathrm{~m}$

$A=\frac{1}{4} \times 3,14 \times 0,2032 \times 0,2032=0,0324 \mathrm{~m}^{2}$

$Q=9,2$ liter $/$ menit $=\frac{9,2}{1 \times 60}=1,53 \times 10^{-4} \mathrm{~m}^{3} /$ detik

$\mathrm{V}=\frac{Q}{A}=\frac{1,53 \times 10^{-4}}{3.24 \times 10^{-2}}=4,73 \times 10^{-3} \mathrm{~m}^{2} /$ detik

$\frac{\Delta P}{0,25}=\frac{150.4,73 \times 10^{-3} 0,9 \times 10^{-6}\left(1-0,4^{2}\right)}{9,81.0,65 .\left(3,2 \times 10^{-2}\right)^{2} \cdot(0,4)^{2}}$

$\Delta P=\frac{5,09 \times 10^{-7}}{2,61 \times 10^{-3}} \times 0,25$

$\Delta P=4,87 \times 10^{-4} \mathrm{~m}$

- Headloss media pasir :

Porositas $=0,3$

koefisien bentuk $\varphi=0,95$

percepatan gravitasi $(\mathrm{g})=9,81 \mathrm{~m} / \mathrm{d}^{2}$

$\mathrm{L}=0,5 \mathrm{~m}$

$\mathrm{d}=1 \mathrm{~mm}=1 \times 10^{-3} \mathrm{~m}$

$A=\frac{1}{4} \times 3,14 \times 0,2032 \times 0,2032=0,0324 \mathrm{~m}^{2}$

$Q=9,2$ liter $/$ menit $=\frac{9,2}{1 \times 60}=1,53 \times 10^{-4} \mathrm{~m}^{3} /$ detik

$\mathrm{V}=\frac{Q}{A}=\frac{1,53 \times 10^{-4}}{3.24 \times 10^{-2}}=4,73 \times 10^{-3} \mathrm{~m}^{2} /$ detik

$\frac{\Delta P}{0,5}=\frac{150.4,73 \times 10^{-3} 0,9 \times 10^{-6}\left(1-O, 3^{2}\right)}{9,81.0,95 .\left(1 \times 10^{-3}\right)^{2} \cdot(0,3)^{2}}$

$\Delta P=\frac{5,81 \times 10^{-7}}{8,38 \times 10^{-7}} \times 0,5$

$\Delta P=0,34 m$

- Headloss media karbon aktif:

Porositas $=0,32$

koefisien bentuk $\varphi=0,73$

percepatan gravitasi $(\mathrm{g})=9,81 \mathrm{~m} / \mathrm{d}^{2}$

$\mathrm{L}=0,75 \mathrm{~m}$

$\mathrm{d}=4 \mathrm{~mm}=5 \times 10^{-3} \mathrm{~m}$

$A=\frac{1}{4} \times 3,14 \times 0,2032 \times 0,2032=0,0324 \mathrm{~m}^{2}$

$Q=9,2$ liter $/$ menit $=\frac{9,2}{1 \times 60}=1,53 \times 10^{-4} \mathrm{~m}^{3} /$ detik

$\mathrm{V}=\frac{Q}{A}=\frac{1,53 \times 10^{-4}}{3.24 \times 10^{-2}}=4,73 \times 10^{-3} \mathrm{~m}^{2} /$ detik

$\frac{\Delta P}{0,75}=\frac{150.4,73 \times 10^{-3} 0,9 \times 10^{-6}\left(1-O, 32^{2}\right)}{9,81.0,73 \cdot\left(8 \times 10^{-3}\right)^{2} \cdot(0,32)^{2}}$ 
$\Delta P=\frac{5,73 \times 10^{-7}}{4,69 \times 10^{-5}} \times 0,75$

$\Delta P=0,3 \mathrm{~m}$

- Headloss media zeolit:

Porositas $=0,32$

koefisien bentuk $\varphi=0,73$

percepatan gravitasi $(\mathrm{g})=9,81 \mathrm{~m} / \mathrm{d}^{2}$

$\mathrm{L}=1 \mathrm{~m}$

$\mathrm{d}=8 \mathrm{~mm}=8 \times 10^{-3} \mathrm{~m}$

$\mathrm{A}=\frac{1}{4} \times 3,14 \times 0,2032 \times 0,2032=0,0324 \mathrm{~m}^{2}$

$Q=9,2$ liter $/$ menit $=\frac{9,2}{1 \times 60}=1,53 \times 10^{-4} \mathrm{~m}^{3} /$ detik

$\mathrm{V}=\frac{Q}{A}=\frac{1,53 \times 10^{-4}}{3.24 \times 10^{-2}}=4,73 \times 10^{-3} \mathrm{~m}^{2} /$ detik

$\frac{\Delta P}{1}=\frac{150.4,73 \times 10^{-3} 0,9 \times 10^{-6}\left(1-O, 32^{2}\right)}{9,81.0,73 \cdot\left(8 \times 10^{-3}\right)^{2} \cdot(0,32)^{2}}$

$\Delta P=\frac{5,73 \times 10^{-7}}{1,83 \times 10^{-5}} x 1$

$\Delta P=0,03 m$

- Headloss media kerikil :

Porositas $=0,4$

koefisien bentuk $\varphi=0,65$

percepatan gravitasi $(\mathrm{g})=9,81 \mathrm{~m} / \mathrm{d}^{2}$

$\mathrm{L}=1,2 \mathrm{~m}$

$\mathrm{d}=32 \mathrm{~mm}=3,2 \times 10^{-2} \mathrm{~m}$

$\mathrm{A}=\frac{1}{4} \times 3,14 \times 0,2032 \times 0,2032=0,0324 \mathrm{~m}^{2}$

$Q=9,2$ liter $/$ menit $=\frac{9,2}{1 \times 60}=1,53 \times 10^{-4} \mathrm{~m}^{3} /$ detik

$\mathrm{V}=\frac{Q}{A}=\frac{1,53 \times 10^{-4}}{3.24 \times 10^{-2}}=4,73 \times 10^{-3} \mathrm{~m}^{2} /$ detik

$\frac{\Delta P}{1,2}=\frac{150.4,73 \times 10^{-3} 0,9 \times 10^{-6}\left(1-0,4^{2}\right)}{9,81.0,65 \cdot\left(3,2 \times 10^{-2}\right)^{2} \cdot(0,4)^{2}}$

$\Delta P=\frac{5,09 \times 10^{-7}}{2,61 \times 10^{-3}} \times 1,2$

$\Delta P=2,34 \times 10^{-4} \mathrm{~m}$

Total Head Loss $=4,87 x 10^{-4}+0,34+0,03+0,03+2,34 x 10^{-4}=0,4 m$

Tinggi alat filter $=1,3 \mathrm{~m}$

Jadi sisa tinggi tekan : Tinggi Tangki- Head Loss $=3-0,4=2,6 \mathrm{~m}$

Sehingga alat filter masih memiliki tekanan

Proses produksi dilakukan dengan proses sedimentasi 4-6 jam sehingga setiap hari dapat dilakukan produksi sebanyak 4 kali produksi atau 4000 liter sedangkan kapasitas pengolahan 3,5 liter/menit atau 210 liter/jam .

Kecepatan aliran pada alat filter akan menggunakan gravitasi pada tangki sedimentasi dan untuk hasil yang efektif, aliran pada saat filtrasi harus dijaga agar laminar dengan bilangan Reynolds, $\mathrm{Re}<$ 1000. Nilai head loss total alat filter $0,4 \mathrm{~m}$ sehingga masih sisa tekan $2,6 \mathrm{~m}$ dan laju produksi alat pengolahan sebesar $20 \%$. 


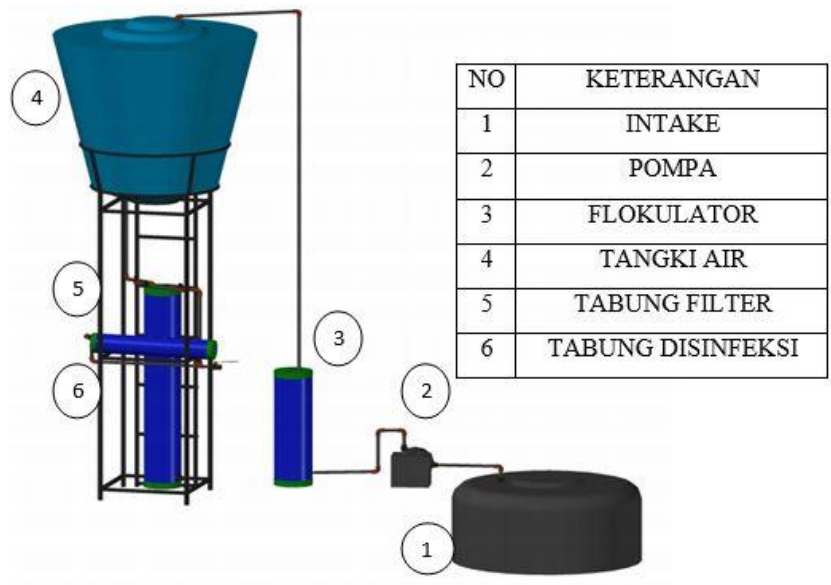

Gambar 3 Desain Unit Pengolahan

\section{Pembahasan}

Dari hasil analisa air olahan rata-rata, parameter fisik air yang sebelumnya tidak memenuhi persyaratan turun setelah melewati alat pengolahan. Pada proses koagulasi dilakukan penambahan koagulan dari alumunium sulfat (tawas) dan proses netralisasi dengan kapur tohor, selanjutnya dilakukan pengadukan (mixer) untuk melarutkan zat kimia (koagulan) dan kapur tohor.

Pada bak sedimentasi air baku yang masih berwarna dan keruh selanjutnya di endapkan terlebih dahulu \pm 4-6 jam lalu di buang ke saluran buangan. Setelah proses sedimentasi, air selanjutnya dialirkan ke tabung filtrasi. Flok-flok atau gumpalan hasil dari tangki sedimentasi yang masih tersisa disaring dengan menggunakan lapisan kerikil, pasir silika, zeolite dan karbon aktif sehingga flok-flok atau gumpalan tersebut tersaring dan menghasilkan air olahan yang jernih dan memenuhi syarat kesehatan.

Tabel 2. Hasil analisa efisiensi alat pengolahan

\begin{tabular}{|c|l|c|c|c|c|c|}
\hline No & Parameter & Standar & Satuan & baku & olahan & Efisiensi \\
\hline 1 & $\mathrm{pH}$ & $6,5-9,5$ & - & 5,5 & 6,8 & \\
\hline 2 & Kekeruhan & 5 & $\mathrm{NTU}$ & 28,3 & 6,7 & $76,21 \%$ \\
\hline 3 & Warna & 15 & Pt.Co & 347 & 10 & $97,12 \%$ \\
\hline 4 & besi & 0,3 & $\mathrm{mg} / \mathrm{l}$ & 0,62 & 0,23 & $62,09 \%$ \\
\hline 5 & Zat Organik & 10 & $\mathrm{mg} / \mathrm{l}$ & 82,16 & 12 & $85,39 \%$ \\
\hline 6 & TDS & 1000 & $\mathrm{mg} / \mathrm{l}$ & 403 & 14,8 & $96,34 \%$ \\
\hline 7 & Total Coliform & 0 & Jml MPN/100 $\mathrm{ml}$ & $17 \times 10^{2}$ & 30 & $98,23 \%$ \\
\hline 8 & E. Coli & $(-)$ & - & $(-)$ & $(-)$ & \\
\hline
\end{tabular}

Pada tabel 2. dapat diketahui efisiensi penggunaan alat pengolahan terhadap penurunan parameter air olahan. Parameter zat organik belum memenuhi Standar Persyaratan Kualitas Air Minum Kesehatan RI No. 492/MENKES/PER/IV/2010 tanggal 19 April 2010 yang seharusnya 10 mg/l akan tetapi pada proses pengolahan terjadi efisiensi penurunan $85,39 \%$. Parameter zat kekeruhan juga belum memenuhi Standar yang seharusnya 5 NTU akan tetapi pada proses pengolahan terjadi efisiensi penurunan $76,21 \%$ dan memenuhi standar baku mutu air sesuai dengan PERMENKES RI NO.416/Menkes/ Per/IX/ 1990 yakni 25 NTU. Berdasarkan karakteristik kimiawi non logam tersebut 
di atas, maka pengolahan air gambut harus mampu menetralisir pH dari 5,5 menjadi dalam kisaran netral (6.5 - 8.5). Alat pengolahan yang diaplikasikan mampu menaikkan pH 5,5 menjadi 6,8.

Hasil analisa parameter kimiawi logam yang dilakukan terhadap air gambut ditampilkan dalam Tabel 3. dari enam (6) parameter logam yang dianalisa, hampir semua berada dalam kisaran normal dibawah ambang baku mutu. Hasil ini tentu saja cukup mempermudah permasalahan dalam rangka meningkatkan kualitas air gambut menjadi air bersih. Sementara itu nilai konsentrasi ammonia 0,9 $\mathrm{mg} / \mathrm{l}$ (baku mutu 1,5 mg/l), nitrat 0,27 mg/l (baku mutu $50 \mathrm{mg} / \mathrm{l}$ ), nitrit 0,036 mg/l (bm $3 \mathrm{mg} / \mathrm{l}$ ), kesadahan $230 \mathrm{mg} / \mathrm{l}$ (baku mutu $500 \mathrm{mg} / \mathrm{l}$ ), sianida 0,007 mg/l (baku mutu 0,07 mg/l) dan sianida $0,007 \mathrm{mg} / \mathrm{l}$ (baku mutu $0,07 \mathrm{mg} / \mathrm{l}$ ).

Tabel 3. Hasil analisa parameter kimiawi logam air baku dan olahan

\begin{tabular}{|c|l|c|c|c|c|}
\hline no & parameter & satuan & baku mutu & air gambut & air olahan \\
\hline 1 & Amoniak & $\mathrm{mg} / \mathrm{l}$ & 1,5 & 0,9 & 0,15 \\
\hline 2 & Nitrat & $\mathrm{mg} / \mathrm{l}$ & 50 & 0,27 & 0,068 \\
\hline 3 & Nitrit & $\mathrm{mg} / \mathrm{l}$ & 3 & 0,02 & 0,005 \\
\hline 4 & sulfat & $\mathrm{mg} / \mathrm{l}$ & 250 & 8 & 2 \\
\hline 5 & kesadahan & $\mathrm{mg} / \mathrm{l}$ & 500 & 230 & 20 \\
\hline 6 & sianida & $\mathrm{mg} / \mathrm{l}$ & 0,07 & 0,007 & 0,001 \\
\hline
\end{tabular}

Dari hasil penelitian dengan menggunakan debit 18 liter/menit setelah melewati proses pengolahan maka menghasilkan 3,5 liter/menit dan total biaya yang dibutuhkan dalam semua proses unit pengolahan sebesar Rp. 5.120.500,- dan perkiraan biaya yang dikeluarakan tiap pengolahan dengan 1000 liter sebesar Rp. 2.550,-,- dan biaya listrik sebesar Rp. 8.049

Agar proses backwash berlangsung efektif maka perlu dijaga kecepatan aliran. Aliran yang lambat akan menyebabkan flok dan partikel yang menempel pada media filter tidak terangkat sedangkan aliran yang terlalu cepat akan menyebabkan media filter ikut terangkat dan terbuang bersama air sisa backwash.

\section{Ucapan Terima Kasih}

Penulis mengucapkan terima kasih yang sebesar-besarnya kepada Allah atas rahmat dan karunia yang telah diberikan selama ini. Kedua orang tua yang telah memberikan semangat dan do'a. Penulis juga mengucapkan terimakasih kepada semua yang membimbing dan mengoreksi jurnal ini sehingga layak di publikasikan serta pengajar di Program Studi Teknik Lingkungan dan laboratorium yang selama ini di pakai untuk penelitian yakni Laboratorium Teknik Lingkungan UNTAN, Laboratorium Pertanian UNTAN dan Laboratorium Dinas Kesehatan Kalimantan Barat.

\section{DAFTAR PUSTAKA}

Kusnaedi, (2006), Mengolah Air Gambut dan Kotor untuk Air Minum, Penebar Swadaya, Jakarta,

Notodarmojo S., (1994), Pengolahan Air Berwarna, Kajian Terhadap Studi Laboratorium, Makalah Lokakarya Pengolahan Air Berwarna, Palangkaraya.

Peraturan Menteri Kesehatan RI No. 492/MENKES/PER/IV/2012 tanggal I9 April 2010

Syarfi, Syamsu Herman, (2007), Rejeksi Zat Organik Air Gambut Dengan Membran Ultrafiltasi, Jurnal Sains dan Teknologi, Jakarta, Vol. XII, Hal. 9-14.

Sutrisno, C, Totok,2006. Teknologi Penyediaan Air Bersih. Rineka Cipta, Jakarta. 